\title{
Problem Based Learning in Basic Education
}

\author{
Eka Nur Samsudin, Murniningsih², Ali Mustadi3 \\ DOI: $10.35445 /$ alishlah.v13i3.749
}

Article Info

Keywords:

Problem Based

Learning,

Basic Education,

Learning Models,

Literature Review

Kata kunci:

Pembelajaran Berbasis

Masalah,

Pendidikan Dasar,

Model Pembelajaran,

Tinjauan Literatur

\begin{abstract}
Using the Problem-Based Learning (PBL) model in elementary school classrooms has been shown to positively impact students' learning outcomes. There are numerous ways in which PBL helps students learn in the primary grades. There is still a paucity of research from reputable national journals on PBL in elementary education for this review. Articles on problem-based learning and the basics of education were pulled from the indexed national education journal Sinta Indonesia as part of the literature review method. Based on the criteria, 16 articles were chosen from the results list. The literature review results show that the PBL model can have a positive impact in general. The research that has been done has improved and had an effect. Elementary school students have made significant strides in a variety of areas, including behavior, attitude, academic performance, and character traits such as initiative, responsibility, cooperation, and critical thinking. Because of PBL's similarities to early childhood education, it should be considered for inclusion there.
\end{abstract}

\begin{abstract}
Abstrak
Tujuan dari tinjauan literatur ini adalah untuk secara sistematis menyelidiki bukti yang ada tentang dampak penerapan model Problem Based Learning (PBL) dalam konteks pembelajaran di pendidikan dasar. PBL memiliki berbagai macam dampak positif terhadap pembelajaran di pendidikan dasar. Masih sedikitnya literatur dari jurnal nasional bereputasi yang membahas mengenai PBL di pendidikan dasar melatar belakangi kajian literatur ini. Metode penelitian menggunakan metode tinjauan literatur, artikel dikumpulkan dari jurnal pendidikan nasional terindeks Sinta Indonesia dengan kata kunci problem based learning dan pendidikan dasar. Dari hasil pencarian diperoleh 16 artikel terpilih berdasarkan kriteria. Temuan tinjauan literatur memperoleh hasil bahwa penggunaan model PBL secara umum dapat berdampak positif. Peningkatan dan pengaruh terjadi dalam penelitian yang telah dilakukan. Baik peningkatan karakteristik, keaktifan, tanggung jawab, kerjasama, kemampuan berpikir kritis, sikap bersahabat/ komunikatif, aktivitas serta hasil belajar siswa sekolah dasar. PBL sesuai dengan karakteristik di pendidikan dasar, sehingga penggunaan PBL di pendidikan dasar patut untuk menjadi bahan pertimbangan.
\end{abstract}

\footnotetext{
${ }^{1}$ Universitas Negeri Yogyakarta, Indonesia

Email: ekanursamsudin1@gmail.com

2 Universitas Sarjanawiyata Tamansiswa, Indonesia

Email: murniningsih@ustjogja.ac.id

3 Universitas Negeri Yogyakarta, Indonesia

Email: ali_mustadi@uny.ac.id
} 


\section{INTRODUCTION}

In the teaching and learning process, Problem Based Learning (PBL) can also be referred to as a problem-based learning model. Problem-based learning (PBL) is a student-centered approach to learning that emphasizes problem-solving at the outset. Students learn by solving real-world problems on their own. Students should be able to put it to good use in their daily lives. Learners in PBL engage in the process of active pedagogy as they progress through various subject areas (Smith \& Hung, 2017). It is important for students to learn how to work as a team and to take responsibility for their education (Alrahlah, 2016). Students are encouraged to learn, work together to solve problems, increase their curiosity, and develop analytical skills and initiative (Zhafirah et al., 2020).

PBL effectively improves student learning outcomes, reduces conceptual difficulties, and prevents the formation of alternative conceptions (Ayyildiz \& Tarhan, 2018). Another advantage of the PBL model is that it generates ideas and encourages students to debate certain issues being discussed (Ismail et al., 2018). Students' argumentative skills accompanied by evidence are central to scientific thinking that helps solve problems (Belland et al., 2011). In general, the use of PBL consists of five stages. 1) Students are oriented to the problems presented, 2) then describe and organize learning tasks, 3) investigate problems, 4) develop and present the work, 5) analyze and evaluate the problem-solving process.

The various advantages and benefits of PBL are one of the reasons PBL is widely used at various levels of education to deliver learning materials. Research using the PBL model has been widely carried out in Indonesian education. As has been done by (Fakhriyah, 2014) describing the application of PBL to develop students' critical thinking skills in the Science Learning course. Toharudin \& Kurniawan (2017) found PBL is used to measure the necessary thinking skills of prospective teacher students. Research by Zulfah et al., (2018) developed student worksheets for PBL-based mathematics for class VIII. (Nugroho et al., 2018) found that PBL is used to measure the ecological literacy ability of class X of Senior High School students. A research study (Alan \& Afriansyah, 2017) determine the difference between the mathematical understanding abilities of junior high school students and PBL.

For students to progress to a higher educational level, they must first complete basic education (Istiningsih \& Nisa, 2015). Students learn various concepts in elementary school that they will build on as they progress through the educational system. Students gain knowledge and skills, develop the social attitudes they'll need in the future, and get a head start on their secondary education through basic education (Ichsan Anshory AM, Erna Yayuk, 2016). An elementary school is a place where children receive a basic education (Widyaningrum \& Hasanudin, 2019). When children reach the end of elementary school, they have developed to think abstractly. Generally, elementary school students are eager to play, move around, work in groups, and receive individual practice instruction (Alim, 2009).

PBL is a type of learning model that has a number of advantages and implications for the delivery of educational materials. However, there is still a dearth of literature on the application of PBL, specifically in elementary education. According to the results of a search in the reputable national journal indexing agency Sinta Indonesia, a substantial amount of literature discussed PBL in the context of general learning. There is still a shortage of literature discussing the PBL model's application in the context of elementary education. The purpose of this review is to conduct a systematic examination of the available evidence regarding the impact of implementing the PBL model in the context of primary education learning. Based on the impact of PBL implementation, it is deemed necessary to conduct additional research, particularly at the elementary education level. 


\section{METHOD}

This research is a type of literature review research that focuses on using problem-based learning models in primary education. The review was conducted by searching for electronic article material in the indexing institution of the National Journal of Sinta Indonesia. The following keywords and keyword combinations are used: problem-based learning, primary education. Search is limited to educational journals category sinta 1 to sinta 3. An article is selected if the abstract is judged according to the context of the research. The criteria used for the literature review are as follows:

Table 1. Literature review criteria

\begin{tabular}{ll}
\hline \hline Kind & Indicators \\
\hline \hline Theme & Articles related to primary education \\
\hline \hline Novelty & Articles published between 2017-2021 \\
\hline \hline Context & $\begin{array}{l}\text { Articles should relate to the use of problem } \\
\text { based learning in primary education. }\end{array}$ \\
\hline Language & The article was posted in Indonesian \\
\hline \hline Research base & Article based on empiris research \\
\hline \hline
\end{tabular}

The author will be presented with several selected article titles that discuss the PBL model in learning in primary education based on the criteria above.

Table 2. Selected article

\begin{tabular}{|c|c|c|}
\hline Author & Title & Journal \\
\hline $\begin{array}{l}\text { Afrenia Wulandari, } \\
\text { Suparno (2020) }\end{array}$ & $\begin{array}{l}\text { Pengaruh Model Problem Based Learning } \\
\text { terhadap Kemampuan Karakter Kerjasama Anak } \\
\text { Usia Dini }\end{array}$ & $\begin{array}{l}\text { Jurnal Obsesi: Jurnal } \\
\text { Pendidikan Anak Usia Dini }\end{array}$ \\
\hline $\begin{array}{lr}\text { Fajar } & \text { Prasetyo, } \\
\text { Firosalia } & \text { Kristin } \\
(2020) & \end{array}$ & $\begin{array}{l}\text { Pengaruh Model Pembelajaran Problem Based } \\
\text { Learning dan Model Pembelajaran Discovery } \\
\text { Learning terhadap Kemampuan Berpikir Kritis } \\
\text { Siswa Kelas } 5 \text { SD }\end{array}$ & $\begin{array}{l}\text { Didaktika Tauhidi: Jurnal } \\
\text { Pendidikan Guru Sekolah } \\
\text { Dasar }\end{array}$ \\
\hline $\begin{array}{l}\text { Risky Priliani } \\
\text { Puspitasari, } \\
\text { Sutarno, I Wayan } \\
\text { Dasna (2020) }\end{array}$ & $\begin{array}{l}\text { Pengaruh Model Problem Based Learning } \\
\text { terhadap Kemampuan Berpikir Tingkat Tinggi dan } \\
\text { Hasil Belajar Siswa Kelas V SD }\end{array}$ & $\begin{array}{l}\text { Jurnal Pendidikan: Teori, } \\
\text { Penelitian, } \\
\text { Pengembangan }\end{array}$ \\
\hline $\begin{array}{l}\text { Rizky Tyas Aria K., } \\
\text { Supriyono } \\
\text { Koeshandayanto, } \\
\text { Sa'dun Akbar } \\
(2020)\end{array}$ & $\begin{array}{l}\text { Perbedaan Higher Order Thinking Skills pada } \\
\text { Model Problem Based Learning dan Model } \\
\text { Konvensional }\end{array}$ & $\begin{array}{l}\text { Jurnal Pendidikan: Teori, } \\
\text { Penelitian, } \\
\text { Pengembangan }\end{array}$ \\
\hline $\begin{array}{l}\text { Irham Nugroho, } \\
\text { Imron (2019) }\end{array}$ & $\begin{array}{l}\text { Implementasi Model Problem Based Learning } \\
\text { (PBL) pada Keterampilan Proses dan Karakter } \\
\text { Islami Peserta Didik dalam Pembelajaran Sains di } \\
\text { Madrasah Ibtidaiyah }\end{array}$ & $\begin{array}{l}\text { Auladuna: Jurnal } \\
\text { Pendidikan Dasar Islam }\end{array}$ \\
\hline $\begin{array}{l}\text { Andika Dinar } \\
\text { Pamungkas, } \\
\text { Firosalia } \\
\text { Kristin, Indri } \\
\text { Anugraheni (2018) } \\
\end{array}$ & $\begin{array}{l}\text { Meningkatkan Keaktifan dan Hasil Belajar Siswa } \\
\text { Melalui Model Pembelajaran Problem Based } \\
\text { Learning (PBL) pada Siswa Kelas 4 SD }\end{array}$ & $\begin{array}{l}\text { Naturalistic: Jurnal Kajian } \\
\text { Penelitan Pendidikan dan } \\
\text { Pembelajaran }\end{array}$ \\
\hline $\begin{array}{l}\text { Arista Khoirul } \\
\text { Mungzilina, } \\
\text { Firosalia Kristin, Indri } \\
\text { Anugraheni (2018) } \\
\end{array}$ & $\begin{array}{l}\text { Penerapan Model Pembelajaran Problem Based } \\
\text { Learning untuk Meningkatkan Tanggung Jawab } \\
\text { dan Hasil Belajar Siswa Kelas } 2 \text { SD }\end{array}$ & $\begin{array}{l}\text { Naturalistic: Jurnal Kajian } \\
\text { Penelitan Pendidikan dan } \\
\text { Pembelajaran }\end{array}$ \\
\hline
\end{tabular}




\begin{tabular}{|c|c|c|}
\hline $\begin{array}{lr}\text { Bella } & \text { Anandya } \\
\text { Yovita O., Mawardi, } \\
\begin{array}{l}\text { Suhandi } \\
(2018)\end{array} \\
\end{array}$ & $\begin{array}{l}\text { Perbedaan Model Problem Based Learning dan } \\
\text { Discovery Learning Ditinjau dari Hasil Belajar } \\
\text { Matematika Siswa Kelas } 4 \text { SD }\end{array}$ & $\begin{array}{l}\text { Scholaria: } \\
\text { Pendidikan } \\
\text { Kebudayaan }\end{array}$ \\
\hline $\begin{array}{l}\text { Naila Filahatin } \\
\text { A., Bambang } \\
\text { Ismanto, Firosalia } \\
\text { Kristin (2018) }\end{array}$ & $\begin{array}{l}\text { Peningkatan Kerjasama dan Hasil Belajar Tematik } \\
\text { Melalui Model Pembelajaran Problem Based } \\
\text { Learning }\end{array}$ & $\begin{array}{l}\text { Naturalistic: Jurnal Kajian } \\
\text { Penelitan Pendidikan dan } \\
\text { Pembelajaran }\end{array}$ \\
\hline $\begin{array}{l}\text { Prasetyo, } \\
(2018)\end{array}$ & $\begin{array}{l}\text { Pengaruh Model Problem Based } \\
\text { Terhadap Hasil Belajar dan Rasa Keingintahuan } \\
\text { Siswa }\end{array}$ & $\begin{array}{l}\text { Didaktika Tauhidi: Jurnal } \\
\text { Pendidikan Guru Sekolah } \\
\text { Dasar }\end{array}$ \\
\hline $\begin{array}{l}\text { Puji Rahayu } \\
\text { Ningsih, } \quad \text { Arif } \\
\text { Hidayat, } \\
\text { Sentot } \quad \text { Kusairi } \\
\text { (2018) }\end{array}$ & $\begin{array}{l}\text { Penerapan Problem Based Learning untuk } \\
\text { Meningkatkan Kemampuan Berpikir Kritis dan } \\
\text { Hasil Belajar Siswa Kelas III }\end{array}$ & $\begin{array}{l}\text { Jurnal Pendidikan: Teori, } \\
\text { Penelitian, } \\
\text { Pengembangan }\end{array}$ \\
\hline $\begin{array}{l}\text { Rahmah Kumullah, } \\
\text { Ery Tri Djatmika, } \\
\text { Lia Yuliati (2018) }\end{array}$ & $\begin{array}{l}\text { Kemampuan Berpikir Kritis dan Penguasaan } \\
\text { Konsep Siswa dengan Problem Based Learning } \\
\text { pada Materi Sifat Cahaya }\end{array}$ & $\begin{array}{l}\text { Jurnal Pendidikan: } \text { Teori, } \\
\text { Penelitian, } \\
\text { Pengembangan }\end{array}$ \\
\hline $\begin{array}{l}\text { Bayu Adji Permana, } \\
\text { Pamujo, Badarudin } \\
\text { (2017) }\end{array}$ & $\begin{array}{l}\text { Peningkatan Sikap Bersahabat/ Komunikatif dan } \\
\text { Prestasi Belajar pada Tema } 8 \text { Daerah Tempat } \\
\text { Tinggalku Menggunakan Model Problem Based } \\
\text { Learning dengan Bantuan Media Gambar Seri }\end{array}$ & $\begin{array}{l}\text { Jurnal Dinamika } \\
\text { Pendidikan Dasar }\end{array}$ \\
\hline $\begin{array}{lr}\text { Nita } & \text { Retno } \\
\text { Wayuningati }(2017)\end{array}$ & $\begin{array}{l}\text { Penerapan Problem Based Learning dan Media } \\
\text { Flipcart untuk Meningkatkan Hasil Belajar IPA } \\
\text { Materi Ekosistem Siswa }\end{array}$ & Jurnal Ilmu Pendidikan \\
\hline $\begin{array}{l}\text { Normala } \\
\text { Rahmadani N., } \\
\text { Indri Anugraheni } \\
(2017)\end{array}$ & $\begin{array}{l}\text { Peningkatan Aktivitas Belajar Matematika Melalui } \\
\text { Pendekatan Problem Based Learning bagi Siswa } \\
\text { Kelas } 4 \text { SD }\end{array}$ & $\begin{array}{l}\text { Scholaria: } \\
\text { Pendidikan } \\
\text { Kebudayaan }\end{array}$ \\
\hline $\begin{array}{l}\text { Reni } \\
(2017)\end{array}$ & $\begin{array}{l}\text { Upaya Meningkatkan Hasil Belajar IPA Materi } \\
\text { Daur Air Melalui Model Pembelajaran Problem } \\
\text { Based Learning }\end{array}$ & $\begin{array}{l}\text { Jurnal Dinamika } \\
\text { Pendidikan Dasar }\end{array}$ \\
\hline
\end{tabular}

\section{FINDINGS AND DISCUSSION}

According to existing research, the application of PBL, in general, may have a beneficial effect. The increase and effect are documented in the research. Both in terms of improving problem-solving abilities, attitudes, cognitive abilities, process skills, and student engagement. To help understanding the major findings of existing research, the following table summarizes the results of literature reviews.

\section{Table 3. Summary of literature review}

\begin{tabular}{|c|c|c|}
\hline Author & esearch methods & Key results \\
\hline $\begin{array}{l}\text { Afrenia } \\
\text { Wulandari, } \\
\text { Suparno } \\
(2020)\end{array}$ & $\begin{array}{l}\text { Pre-experimental with one group of } \\
\text { experiments using pretest and posttest. } \\
\text { Data collection tool: observation sheet. }\end{array}$ & $\begin{array}{l}\text { Significant differences in control classes and } \\
\text { experiments showed differences in the } \\
\text { character's ability to cooperate through } \\
\text { problem-based learning model learning. }\end{array}$ \\
\hline $\begin{array}{l}\text { Fajar Prasetyo, } \\
\text { Firosalia } \\
\text { Kristin (2020) }\end{array}$ & $\begin{array}{l}\text { Pseudo-experimental research with } \\
\text { pretest-posttest control group design. } \\
\text { Data collection: tests and observations. }\end{array}$ & $\begin{array}{l}\text { The critical thinking skills of experimental } \\
\text { classroom students are higher than those of } \\
\text { control classes. Based on the analysis of } \\
\text { data, it was concluded that the PBL model } \\
\text { had a significant effect on the critical } \\
\text { thinking skills of 5th graders. }\end{array}$ \\
\hline
\end{tabular}


Risky Priliani Quasi experiment research design Puspitasari, Sutarno, Wayan Dasna (2020) nonequivalent control group. Data collection: about tests. Parametric inferential $\quad$ statistical analysis techniques.

$\begin{array}{ll}\text { Rizky Tyas } & \\ \text { Aria K., } & \text { Quantitative research experiments with } \\ \text { Supriyono } & \text { nonequivalent group design. Data } \\ \text { Koeshandayan } & \text { collection: tests and observation sheets. } \\ \text { to, Sa'dun } & \text { Covariance analysis technique } \\ \text { Akbar (2020) } & \text { (ANCOVA). }\end{array}$

\begin{tabular}{ll}
\hline \hline Irham & Qualitative approach to action research \\
Nugroho, & methods. Data collection: tests, \\
Imron (2019) & $\begin{array}{l}\text { questionnaires, observations, field } \\
\text { records, documentation. }\end{array}$
\end{tabular}

Andika Dinar

Ultimate,

Firosalia

Kristin, Indri

Anugraheni

Study class 2 cycle actions. Data collection: tests, observational data, rubrics of liveliness assessment.

Quantitative research experiments with (2018)

Arista Khoirul

Mungzilina,

Firosalia

Kristin, Indri

Anugraheni

(2018)

Bella Anandya

Yovita O., Quasi experimental research with pre-

Mawardi, test and post-test. Data collection:

Suhandi Astuti about tests.

Study class 2 cycle actions. Data collection: observations,

Through the application of PBL can increase questionnaires, and tests. the responsibility and learning outcomes of grade II elementary school students.

Through the application of the PBL learning model can improve the activeness and learning outcomes of grade IV elementary school students. students. There has been an increase in high-level thinking skills and student learning outcomes. There was no significant difference in the positive learning outcomes of high- and low-skilled early-capable students.

The implementation of the teacher is sufficient in accordance with the syntax of the PBL learning model so that it can affect the student's HOTS. HOTS scores with PBL models are higher than with conventional models. The use of the PBL model should be implemented to students in order to train HOTS students.

Through process skills with the PBL model can shape and enhance the Islamic characteristics of students in science subjects.

Math learning outcomes using the PBL learning model were significantly higher compared to the Discovery Learning model.. (2018)

\section{Naila Filahatin}

A., Bambang

Ismanto,

Firosalia

Kristin (2018)

\begin{tabular}{|c|c|c|}
\hline $\begin{array}{l}\text { Prasetyo, Nisa } \\
(2018)\end{array}$ & $\begin{array}{l}\text { Quantitative research design } \\
\text { nonequivalent control group design. } \\
\text { Data collection: tests, questionnaires, } \\
\text { observations. }\end{array}$ & $\begin{array}{l}\text { There is a significant positive influence on } \\
\text { the PBL model on curiosity and the output } \\
\text { of study grades/ learning outcomes of grade } \\
\text { V elementary school students. }\end{array}$ \\
\hline $\begin{array}{l}\text { Praise Rahayu } \\
\text { Ningsih, Arif } \\
\text { Hidayat, } \\
\text { Sentot Kusairi } \\
\text { (2018) }\end{array}$ & $\begin{array}{l}\text { Study class } 3 \text { cycle actions. } \\
\text { collection: tests, observations, field } \\
\text { records. }\end{array}$ & $\begin{array}{l}\text { There is an improvement in critical thinking } \\
\text { skills and student learning outcomes } \\
\text { through the PBL model. }\end{array}$ \\
\hline $\begin{array}{l}\text { Rahmah } \\
\text { Kumullah, Ery } \\
\text { Tri Djatmika, } \\
\text { Lia Yuliati } \\
\text { (2018) }\end{array}$ & $\begin{array}{l}\text { Quasy research experiments with } \\
\text { pretest-posttest. Data collection: the } \\
\text { question of critical thinking skills test in } \\
\text { the form of essays and IPA concept } \\
\text { mastery tests in the form of multiple } \\
\text { choices. }\end{array}$ & $\begin{array}{l}\text { Critical thinking skills and mastery of IPA } \\
\text { concepts of students who apply the PBL } \\
\text { model are higher than those taught by } \\
\text { conventional models. }\end{array}$ \\
\hline
\end{tabular}

Study class 2 cycle actions. Data There is an increase in cooperation and collection: observations, thematic learning outcomes of students documentation, and written tests. through the PBL learning model.

Significant differences in HOTS between experimental and control classroom 


\begin{tabular}{|c|c|c|}
\hline $\begin{array}{l}\text { Bayu Adji } \\
\text { Permana, } \\
\text { Pamujo, } \\
\text { Badarudin } \\
(2017)\end{array}$ & $\begin{array}{l}\text { Study class } 2 \text { cycle actions. Data } \\
\text { collection: teacher activity sheets, } \\
\text { evaluation tests, attitude scale sheets, } \\
\text { observation sheets. }\end{array}$ & $\begin{array}{l}\text { Improved friendly / communicative attitude } \\
\text { and learning achievement can be done using } \\
\text { the PBL model with the help of serial image } \\
\text { media. }\end{array}$ \\
\hline $\begin{array}{l}\text { Nita Retno } \\
\text { Wayuningati } \\
(2017)\end{array}$ & $\begin{array}{l}2 \text { cycle action research with the Kemmis } \\
\text { \&Taggart model. Data collection: } \\
\text { observation, documentation, and tests. }\end{array}$ & $\begin{array}{l}\text { The application of the PBL model and Flip- } \\
\text { cart media can improve the learning } \\
\text { outcomes of grade V elementary school } \\
\text { students. }\end{array}$ \\
\hline $\begin{array}{l}\text { Normala } \\
\text { Rahmadani } \\
\text { N., } \\
\text { Indri } \\
\text { Anugraheni } \\
\text { (2017) }\end{array}$ & $\begin{array}{l}\text { Study class } 2 \text { cycle actions. Data } \\
\text { collection: non-test techniques of } \\
\text { student learning activities. }\end{array}$ & $\begin{array}{l}\text { Significant improvement in math learning } \\
\text { activities with PBL. Students are directly } \\
\text { involved in solving a problem given by the } \\
\text { teacher and the teacher acts as a facilitator. }\end{array}$ \\
\hline $\begin{array}{l}\text { Reni Setiowati } \\
(2017)\end{array}$ & $\begin{array}{l}\text { Study class } 2 \text { cycle actions. Data } \\
\text { collection: tests, observations. }\end{array}$ & $\begin{array}{l}\text { The PBL learning model can improve IPA } \\
\text { learning outcomes in grade V elementary } \\
\text { school students. }\end{array}$ \\
\hline
\end{tabular}

Trained problem-solving skills with various cases are given early in learning as a key requirement of part of the PBL model. With cases that are always there and getting more complicated, it is increasingly difficult at each stage to participate in the impact on students' ability to solve problems. Creating authentic problems trains alternative knowledge in solving problems and enriching students' knowledge.

Students' thinking skills must be developed by optimizing systematic group/teamwork processes in the PBL model (Waraulia, 2016). Through the group work process, problem-solving activities have various aspects of attitude such as caring, responsible, and honesty. This aspect of attitude will develop in line with the problem-solving process. Islamic characteristics of students in the problem-solving process have improved with the PBL model (I. Nugroho \& Imron, 2019). A significant improvement in the picture of Islamic characteristics suggests that the PBL model impacts attitudes.

Improvements in students' cognitive abilities can be seen from the results and learning achievements that have been achieved. PBL with complex syntax trains various domains in thinking skills, one of which is the cognitive realm. Learning design by training the brain to think and find an alternative solution to problem-solving impacts students' cognitive abilities. The application of PBL can improve student learning outcomes. Based on the research results at the existing elementary school level, the application of PBL at all levels of elementary school classes results in a significant increase in learning outcomes. By the opinion expressed (Gündüz et al., 2016), learning methods and models influence learning outcomes. In addition, increased student activity also impacts learning outcomes of cognitive aspects of students who increase. Through problem-solving models, students develop their cognitive abilities as well as language skills. It's like connecting similar things or classifying them. Thinking concrete abstract is an important part of developing students' cognitive abilities (Burhaein, 2017).

Improvement of process skills as a result of the application of PBL is seen from the activities of students who are carried out gradually in acquiring their knowledge. Through the development and presentation of students' work, they have acquired their own knowledge, which is then communicated through the stages of analyzing and evaluating the problem-solving process. Process science skills can be significantly improved to interpret and observe through the PBL model (Susanto, 2017). As expressed by (Marjan et al., 2014), science as a process is to put forward principles, concepts, and laws about natural symptoms that require systematic and structured treatment.

The improvement of student activity through PBL focuses on elementary school students' characteristics, specifically happy groups. Participate in influencing students' activity levels through 
the use of work and group discussions in PBL. Along with the presentation of problems, students are required to solve them actively, both independently and in groups. Student engagement can be observed during group discussion activities based on research observations when the PBL model is used in learning. This is consistent with the views expressed by (Wibowo, 2016). The learning model can increase student activity according to indicators such as cooperation, attention and social relationships, ideas/opinions, ability to solve problems, and discipline.

The application of the PBL model impacts various aspects, both cognitive, affective, and psychomotor aspects of students. The PBL model in learning can improve the characteristics, liveliness, responsibility, cooperation, critical thinking skills, friendly/communicative attitudes, and learning activities of students in elementary school. Student learning outcomes have also improved. Improved student learning outcomes can be obtained from each subject taught through the PBL model. Both in the learning of IPA, IPS, Indonesian, Mathematics, PPKn, SBdP, PJOK, and Religion. The opinion supports this (Sofyan et al., 2016) need to be convinced that PBL is a learning that can be applied in supporting learning in the 2013 curriculum.

The application of the PBL model in elementary schools can stand alone without the use of learning media or combined with the use of learning media. The use of learning media is intended so that the application of PBL can involve students more actively in the use of media, which later impacts the activeness of students in the learning activity process. Media combinations used in PBL include flip-cart, series images, interactive multimedia. In general, all learning media can be combined with the PBL model, but with adjustments in PBL syntax in their use. This is supported by various research on the development of PBL-based learning media, such as those conducted by (Sari et al., 2021), which develops PBL-based IPS and Snakes \& Ladders-based interactive learning media. The results showed this medium was worth using in grade IV elementary school IPS subjects. Research conducted by (Permatasari et al., 2018) developed a model of PBL and simple aircraft media (Probalpena) to improve the learning outcomes of IPA students of grade $\mathrm{V}$ elementary school.

The provision of up-to-date issues trains students to be sensitive to the surrounding environment and emerging issues. Students are directly involved in solving a problem given by the teacher, and the teacher acts as a facilitator. Based on the problems provided in PBL has an increased impact on the ability to think high level or HOTS students. The PBL model should be implemented to students to train HOTS students (Kurniasari et al., 2020). Especially in elementary school.

\section{CONCLUSION}

It is critical to introduce concepts of learning in primary school in order to better prepare students for secondary school. The ability of students to comprehend course material is directly correlated to the degree to which the PBL model is used in the classroom. The literature review findings show that the PBL model, in general, can be beneficial. In the research, there is an increase and an effect. Both boosted elementary school students' vitality, responsibility, cooperation, and critical thinking abilities, as well as their friendliness and communicative attitudes and the activities they engaged in. In line with the characteristics of primary school students, such as their willingness to move around, work in groups, and engage in hands-on practice, PBL is an excellent fit. Problemsolving also helps children in the primary school develop their cognitive abilities and language skills and their ability to communicate. The PBL model can be used in elementary school classrooms as a standalone strategy with or without learning media. As a result, incorporating PBL into early childhood education should be considered. The PBL model should be used in primary education for more specialized subjects like IPA, mathematics, and Indonesian, according to future research recommendations. Use of PBL in online learning. The PBL model is being used in online education for primary school students. 


\section{REFERENCES}

Ajria, N. F., Ismanto, B., \& Kristin, F. (2018). Peningkatan Kerjasama dan Hasil Belajar Tematik Melalui Model Pembelajaran Problem Based Learning. Naturalistic: Jurnal Kajian Penelitan Pendidikan Dan Pembelajaran, 3(1), 254-268.

Alan, U. F., \& Afriansyah, E. A. (2017). Kemampuan Pemahaman Matematis Siswa Melalui Model Pembelajaran Auditory Intellectualy Repetition dan Problem Based Learning. Jurnal Pendidikan Matematika, 11(1), 68-77.

Alim, A. (2009). Permainan Mini Tenis untuk Pembelajaran Pendidikan Jasmani Olahraga dan Kesehatan Siswa di Sekolah Dasar. JPJI, 6(2), 82.

Alrahlah, A. (2016). How effective the problem-based learning (PBL) in dental education. A critical review. Saudi Dental Journal, 28(4), 155-161. https://doi.org/https://doi.org/10.1016/j.sdentj.2016.08.003

Ayyildiz, Y., \& Tarhan, L. (2018). Problem-based learning in teaching chemistry: enthalpy changes in systems. Research in Science \& Technological Education, 36(1), 35-54. https://doi.org/10.1080/02635143.2017.1366898

Belland, B. R., Glazewski, K. D., \& Richardson, J. C. (2011). Problem-based learning and argumentation: Testing a scaffolding framework to support middle school students' creation of evidence-based arguments. Instructional Science, 39, 667-694. https://doi.org/https://doi.org/10.1007/s11251-010-9148-z

Burhaein, E. (2017). Aktivitas Fisik Olahraga untuk Pertumbuhan dan Perkembangan Siswa SD. Indonesian Journal of Primary Education, 1(1), 51-58. http://ejournal.upi.edu/index.php/IJPE/index

Fakhriyah, F. (2014). Penerapan Problem Based Learning dalam Upaya Mengembangkan Kemampuan Berpikir Kritis Mahasiswa. Jurnal Pendidikan IPA Indonesia, 3(1), 95-101.

Gündüz, A. Y., Alemdağ, E., Yaşar, S., \& Erdem, M. (2016). Design of a problem-based online learning environment and evaluation of its effectiveness. Turkish Online Journal of Educational Technology, 15(3), 49-57.

Ichsan Anshory AM, Erna Yayuk, D. W. E. (2016). Tahapan dan Karakteristik Perkembangan Belajar Siswa Sekolah Dasar (Upaya Pemaknaan Development Task). The Progressive and Fun Education Seminar, ISBN: 978-, 383-389. https://publikasiilmiah.ums.ac.id

Ismail, N. S., Harun, J., Zakaria, M. A. Z. M., \& Salleh, S. M. (2018). The effect of Mobile problembased learning application DicScience PBL on students. Think. Ski. Creat, 28, 177-195. https://doi.org/https://doi.org/10.1016/j.tsc.2018.04.002

Istiningsih, \& Nisa, A. F. (2015). Implementasi Multiple Intellegences. Al-Bidayah, 7(2), 182-196.

Kumullah, R., Djatmika, E. T., \& Yuliati, L. (2018). Kemampuan Berpikir Kritis dan Penguasaan Konsep Siswa dengan Problem Based Learning pada Materi Sifat Cahaya. Jurnal Pendidikan: Teori, Penelitian, Dan Pengembangan, 3(12), 1583-1586. https://doi.org/DOAJSHERPA/RoMEO-Google Scholar-IPI

Kurniasari, R. T. A., Koeshandayanto, S., \& Akbar, S. (2020). Perbedaan Higher Order Thinking Skills pada Model Problem Based Learning dan Model Konvensional. Jurnal Pendidikan: Teori, Penelitian, Dan Pengembangan, 5(2), 170-174. https://doi.org/DOAJSHERPA/RoMEO-Google Scholar-IPI

Marjan, J., Arnyana, I. B. P., \& Setiawan, I. G. A. N. (2014). Pengaruh Pembelajaran Pendekatan Saintifik terhadap Hasil Belajar Biologi dan Keterampilan Proses Sains Siswa MA Mu'allimat NW Pancor Selong Kabupaten Lombok Timur Nusa Tenggara Barat. Jurnal Pendidikan Dan Pembelajaran IPA Indonesia, 4(1), 1-12.

Mungzilina, A. K., Kristin, F., \& Anugraheni, I. (2018). Penerapan Model Pembelajaran Problem Based Learning untuk Meningkatkan Tanggung Jawab dan Hasil Belajar Siswa Kelas 2 SD. Naturalistic: Jurnal Kajian Penelitan Pendidikan Dan Pembelajaran, 2(2), 184-195.

N., N. R., \& Anugraheni, I. (2017). Peningkatan Aktivitas Belajar Matematika Melalui Pendektan Problem Based Learning bagi Siswa Kelas 4 SD. Scholaria: Jurnal Pendidikan Dan Kebudayaan, $7(3), 241-250$.

Ningsih, P. R., Hidayat, A., \& Kusairi, S. (2018). Penerapan Problem Based Learning untuk Meningkatkan Kemampuan Berpikir Kritis dan Hasil Belajar Siswa Kelas III. Jurnal Pendidikan: Teori, Penelitian, Dan Pengembangan, 3(12), 1587-1593. https://doi.org/DOAJSHERPA/RoMEO-Google Scholar-IPI

Nugroho, I., \& Imron. (2019). Implementasi Model Problem Based Learning (PBL) pada 
Keterampilan Proses dan Karakter Islami Peserta Didik dalam Pembelajaran Sains di Madrasah Ibtidaiyah. AULADUNA: Jurnal Pendidikan Dasar Islam, 6(2), 130-137. https://doi.org/https://doi.org/10.24252/auladuna.v6i2a3.2019

Nugroho, L. A., Prayitno, B. A., \& Karyanto, P. (2018). Efektivitas Model Pembelajaran Problem Based Learning terhadap Kemampuan Literasi Ekologi Siswa Kelas X Sekolah Menengah Atas. Jurnal Konseling Dan Pendidikan, 6(1), 1-7.

Oktaviani, B. A. Y., Mawardi, \& Astuti, S. (2018). Perbedaan Model Problem Based Learning dan Discovery Learning Ditinjau Dari Hasil Belajar Matematika Siswa Kelas 4 SD. Scholaria: Jurnal Pendidikan Dan Kebudayaan, 8(2), 132-141.

Pamungkas, A. D., Kristin, F., \& Anugraheni, I. (2018). Meningkatkan Keaktifan dan Hasil Belajar Siswa Melalui Model Pembelajaran Problem Based Learning (PBL) pada Siswa Kelas 4 SD. Naturalistic: Jurnal Kajian Penelitan Pendidikan Dan Pembelajaran, 3(1), 287-293.

Permana, B. A., Pamujo, \& Badarudin. (2017). Peningkatan Sikap Bersahabat/ Komunikatif dan Prestasi Belajar pada Tema 8 Daerah Tempat Tinggalku Menggunakan Model Problem Based Learning dengan Bantuan Media Gambar Seri. Dinamika Pendidikan Dasar, 10(1), 1-7.

Permatasari, N. E., Koeswati, H. D., \& Giarti, S. (2018). Pengembangan Model Pembelajaran Problem Based Learning dan Pesawat Sederhana (Probalpena) untuk Meningkatkan Hasil Belajar IPA Siswa Kelas V SDN Karanganyar 01. Muallimuna: Jurnal Madrasah Ibtidaiyah, $3(2), 116-127$.

Prasetyo, F., \& Kristin, F. (2020). Pengaruh Model Pembelajaran Problem Based Learning dan Model Pembelajaran Discovery Learning terhadap Kemampuan Berpikir Kritis Siswa Kelas 5 SD. Didaktika Tauhidi: Jurnal Pendidikan Guru Sekolah Dasar, 7(1), 13-27.

Prasetyo, T., \& Nisa, K. (2018). Pengaruh Model Problem Based Learning Terhadap Hasil Belajar dan Rasa Keingintahuan Siswa. Didaktika Tauhidi: Jurnal Pendidikan Guru Sekolah Dasar, 5(2), 83-93.

Puspitasari, R. P., Sutarno, \& Dasna, I. W. (2020). Pengaruh Model Problem Based Learning terhadap Kemampuan Berpikir Tingkat Tinggi dan Hasil Belajar Siswa Kelas V SD. Jurnal Pendidikan: Teori, Penelitian, Dan Pengembangan, 5(4), 503-511. https://doi.org/DOAJSHERPA/RoMEO-Google Scholar-IPI

Sari, D. P. P., Murtono, \& Utomo, S. (2021). Pengembangan Media Pembelajaran Interaktif IPS Berbasis Problem Based Learning dan Ular Tangga. JPE (Jurnal Pendidikan Edutama), 8(1), $1-11$.

Setiowati, R. (2017). Upaya Meningkatkan Hasil Belajar IPA Materi Daur Air Melalui Model Pembelajaran Problem Based Learning. Dinamika Pendidikan Dasar, 1o(1), 21-27. http://erepository.perpus.iainsalatiga.ac.id/id/eprint/1875

Smith, C. S., \& Hung, L. C. (2017). Using problem-based learning to increase computer self-efficacy in Taiwanese students. Interactive Learning Environments, 25(3), 329-342. https://doi.org/10.1080/10494820.2015.1127818

Sofyan, H., Komariah, K., \& Wagiran. (2016). Problem Based Learning dalam Implementasi Kurikulum 2013 di SMK. Seminar Nasional 2016 "Professional Responsibility Pendidik Dalam Menyiapkan SDM Vokasi Abad 21," 24-35.

Susanto, S. (2017). Pengembangan Perangkat Pembelajaran IPA dengan Model Problem Based Learning untuk Meningkatkan Keterampilan Berpikir Kritis Siswa Kelas IV Sekolah Dasar. Jurnal Pendidikan Dasar Nusantara, 3(1), 130-143. https://doi.org/10.29303/jpm.v14i2.1136

Toharudin, U., \& Kurniawan, I. S. (2017). Penerapan Model Pembelajaran Problem Based Learning untuk Mengukur Kemampuan Berpikir Kritis Mahasiswa Calon Guru pada Mata Kuliah Psikologi Pendidikan. Jurnal Konseling Dan Pendidikan, 5(1), 1-10. http://jurnal.konselingindonesia.com

Waraulia, A. M. (2016). Penerapan Metode Problem Based Learning dan Media Gambar dalam Pembelajaran Membaca Cerita. Premiere Educandum: Jurnal Pendidikan Dasar Dan Pembelajaran, 6(01), 122-134. https://doi.org/10.25273/pe.v6io1.301

Wayuningati, N. R. (2017). Penerapan Problem Based Learning dan Media Flipcart Untuk Meningkatkan Hasil Belajar IPA Materi Ekosistem Siswa. Jurnal Ilmu Pendidikan, 2(2), 184188.

Wibowo, N. (2016). Upaya Peningkatan Keaktifan Siswa Melalui Pembelajaran Berdasarkan Gaya Belajar di SMK Negeri 1 Saptosari. Jurnal Electronics, Informatics, and Vocational Education 
(ELINVO), 1(2), 128-139.

Widyaningrum, K. H., \& Hasanudin, C. (2019). Kajian Kesulitan Belajar Membaca Menulis Permulaan (MMP) di Sekolah Dasar. Jurnal Pendidikan, 2.

Wulandari, A., \& Suparno. (2020). Pengaruh Model Problem Based Learning terhadap Kemampuan Karakter Kerjasama Anak Usia Dini. Jurnal Obsesi: Jurnal Pendidikan Anak Usia Dini, 4(2), 862-872. https://doi.org/10.31004/obsesi.v4i2.448

Zhafirah, T., Erna, M., \& Rery, R. U. (2020). Development Of E-Modul Based On Problem Based Learning (PBL) in Hydrocarbon Material. Al-Ishlah: Jurnal Pendidikan, 12(2), 216-229. https://doi.org/10.35445/alishlah.v12.i2.263

Zulfah, Fauzan, A., \& Armiati. (2018). Pengembangan Lembar Kerja Peserta Didik Berbasis Problem Based Learning untuk Materi Matematika Kelas VIII. Journal Pendidikan Matematika, 12(2), $33-46$. 